Jurnal Ilmu Ilmu Agribisnis: Journal of Agribusiness Science, 9(4), November 2021

\title{
SIKAP DAN KEPUASAN KONSUMEN DALAM PEMBELIAN BOLEN PISANG CVMAYANG SARI DI KOTA BANDAR LAMPUNG
}

\author{
(Attitude and Customer Satisfaction in Purchasing Banana Bolen CV Mayang Sari \\ in Bandar Lampung City)
}

Reza Dwi Meisanto, Rabiatul Adawiyah, Eka Kasymir

Jurusan Agribisnis, Fakultas Pertanian, Universitas Lampung, Jl. Prof. Dr. Soemantri Brodjonegoro

No. 1 Bandar Lampung 35145, Telp. 085365306419, e-mail: rabiatul.adawiyah@fp.unila.ac.id

\begin{abstract}
This study aims to determine attitudes, purchasing patterns and customer satisfaction on banana bolen CV Mayang Sari. This research method uses a survey method. Samples of this study consisted of 40 consumers who had purchased and / or consumed banana bolen 3 times. The data analysis methods used were descriptive, Fishbein's Multi-attribute model, Customer Satisfaction Index (CSI) and Importance Performance Analysis (IPA). The attributes used in this study are price, taste, flavor variants, size, texture, product packaging, and accessibility). The results showed that consumers liked banana bolen or had a good attitude with an Ao value of 132.52, the pattern of buying banana bolen CV Mayang Sari by 52.50 percent consumers, namely two boxes (20 pieces) of banana bolen in one transaction with the flavor variant that consumers are most interested in is chocolate 55 percent. The frequency of consumer purchases is 90 percent made once a month, customer Satisfaction Index (CSI) in consuming banana bolen CV Mayang Sari is in the very satisfied criteria, which is equal to 83.82 percent. Based on Importance Performance Analysis (IPA), there is one attribute that falls into quadrant I (Main Priority), namely the taste attribute. In quadrant II (Maintain Achievement) there is one attribute, namely the price attribute, while in quadrant III (Low Priority) there are attributes of size and ease of obtaining products, and in quadrant IV (Excessive) there are several attributes, namely texture, flavor variants, and product packaging.
\end{abstract}

Key words: attitude, banana bolen, CSI, IPA

\section{PENDAHULUAN}

Pisang merupakan salah satu komoditas yang memiliki prospek baik untuk dikembangkan menjadi produk pangan olahan. Provinsi Lampung merupakan salah satu provinsi dengan produksi buah pisang tertinggi dimana memiliki luas tanam sebesar 1.462.423 ha pada tahun 2017 (Direktorat Jenderal Hortikultura 2017).

Pisang merupakan buah yang mengandung gizi tinggi, mudah didapat dan harganya terjangkau sebagai sumber vitamin, mineral, karbohidrat, serat dan vitamin A, B, C, serta menjaga kondisi tetap kenyang dalam waktu lama. Selain mengandung gizi yang tinggi, buah pisang juga dapat diolah menjadi berbagai macam makanan seperti bolen pisang, keripik pisang, sale pisang, bolu pisang, brownis pisang, pie dan dodol pisang sehingga dapat meningkatkan nilai tambah yang tinggi.

Terdapat enam toko yang menjual bolen pisang di
Kota Bandar Lampung yaitu Holland Bakery, Yussy Akmal, Shereen Cake \& Bread, Lakita Bakery, Jaya Bakery, dan CV Mayang Sari. CV Mayang Sari didirikan sejak tahun 2010 dan memproduksi berbagai macam produk seperti bolen pisang, donut, roti manis, roti unyil, Muffin, cheese roll, dan chocolate roll. CV Mayang Sari lebih banyak memproduksi bolen pisang sebanyak seribu buah dibandingkan dengan jenis produk yang lain, dikarenakan bolen pisang pada CV Mayang Sari merupakan kue yang disukai dan kue pertama yang dicari konsumen saat mendatangi took tersebut.

Ketika memutuskan akan membeli suatu produk tentu saja konsumen selalu memikirkan terlebih dahulu produk apa yang akan dibeli, mulai dari rasa, harga, varian rasa, ukuran, tekstur, kemasan produk, dan kemudahan memperoleh. Setelah melihat atribut yang diberikan oleh agroindustri tersebut tentunya dapat mempengaruhi sikap konsumen apakah konsumen tersebut akan membeli produk yang ditawarkan atau tidak. 
Apabila atribut yang diberikan dapat diterima oleh konsumen maka akan didapatkan kepuasan dari konsumen tersebut setelah membeli atau mengkonsumsi produk tersebut.

CV Mayang Sari tentunya harus memperhatikan atribut yang diberikan kepada konsumen seperti rasa, harga, varian rasa, ukuran, tekstur, kemasan produk, dan kemudahan memperoleh. Atributatribut tersebut dapat mempengaruhi sikap dan kepuasan konsumen terhadap produk yang dibelinya apakah sesuai dengan apa yang diinginkan atau tidak, serta puas atau tidak terhadap produk yang dikonsumsinya. Tingkat kepuasan konsumen akan menentukan pola pembelian. Pola pembelian meliputi jumlah, jenis dan frekuensi produk bolen pisang.

untuk mengukur tingkat kepuasan konsumen yaitu dilihat dari kualitas atau mutu yang baik dari suatu produk yang meliputi barang dan jasa. Apabila kualitas produk yang ditawarkan lebih besar dari harapan konsumen, maka kepuasan akan terbentuk. Sebaliknya, jika kualitas yang ditawarkan lebih rendah dari harapan maka konsumen akan merasa tidak puas (Supranto 2006).

Konsumen yang merasa puas akan melakukan pembelian ulang dan menjadi pelanggan tetap. Sebaliknya, konsumen yang merasa tidak puas akan menciptakan kesan negatif dan tidak akan menjadi pelanggan tetap. Peningkatan pembelian konsumen juga tidak terlepas dari bagaimana CV Mayang Sari mempromosikan produknya agar dikenal oleh banyak kalangan dengan mempertahankan harga, rasa, varian rasa, ukuran, tekstur, kemasan produk, dan kemudahan memperoleh.. Berdasarkan uraian latar belakang, maka penelitian ini bertujuan untuk mengetahui sikap konsumen, pola pembelian konsumen, dan tingkat kepuasan konsumen dalam pembelian bolen pisang di CV Mayang Sari Kota Bandar Lampung.

\section{METODE PENELITIAN}

Penelitian ini menggunakan metode survei. Menurut Sugiyono (2012) metode survei adalah metode penelitian yang dilakukan pada populasi besar maupun kecil, tetapi data yang dipelajari dalam metode ini adalah data dari sampel yang diambil dari populasi tersebut.

Penelitian ini dilakukan di CV Mayang Sari Kota Bandar Lampung. Pemilihan lokasi ini dilakukan secara sengaja (purposive) dengan pertimbangan agroindustri tersebut sudah lama berdiri dan produknya banyak digemari oleh masyarakat Kota Bandar Lampung. Jumlah responden pada penelitian ini adalah 35 responden.

Menurut Sugiyono (2012) Skor ideal (kriterium) merupakan skor yang digunakan untuk menghitung skor rating scale dan jumlah seluruh jawaban yang didapatkan dari skor jawaban tiap pertanyaan dikalikan dengan jumlah responden digunakan rumus sebagai berikut :

\section{Skor Kriterium $=$ Nilai skala $\times$ Jumlah responden}

Metode pengambilan sampel yang digunakan dalam penelitian ini adalah metode Non Probability Sampling yaitu Accidental Sampling. Menurut Sugiyono (2012) Accidental Sampling adalah mengambil sampel berdasarkan kebetulan, yaitu siapa saja yang secara kebetulan bertemu dengan peneliti serta memenuhi kriteria. Kriteria responden bolen pisang dalam penelitian ini : (1) berusia 17 tahun ke atas (2) konsumen pernah membeli bolen pisang minimal tiga kali dalam kurun waktu 6 bulan terakhir (3) bersedia di wawancarai atau mengisi kuesioner yang telah disediakan. Pengumpulan data dilakukan pada bulan Juli 2019 - Agustus 2019.

Penentuan jumlah sampel digunakan teknik teori Malhotra (2006) yaitu paling sedikit empat atau lima kali dari jumlah item pertanyaan atau variabel. Dalam penelitian ini terdapat 7 item variable atribut produk. Sehingga jumlah sampel yang diambil dalam penelitian ini adalah 35 sampel (7 item variable atribut x 5).

Sebelum kuesioner digunakan untuk mengumpulkan data terlebih dahulu dilakukan uji validitas dan reliabilitas. Ghozali (2009) menyatakan bahwa uji validitas digunakan untuk mengukur sah atau valid tidaknya suatu kuesioner. Nilai validitas dapat dikatakan baik, jika nilai corrected item dari total correlation bernilai di atas 0,20 . Apabila nilai correlation di atas 0,20 maka butir-butir tersebut daikatakan valid.

Uji Reliabilitas merupakan indeks yang menunjukkan sejauh mana suatu alat pengukur dapat dipercaya atau dapat diandalkan. Realibilitas digunakan untuk mengetahui kereliabelan dari atribut-atribut yang diajukan pada responden dalam kuesioner (Ghozali 2009). 
Tabel 1. Hasil uji validitas dan reliabilitas atribut tingkat kepentingan bolen pisang $\mathrm{CV}$ Mayang Sari

\begin{tabular}{lcc}
\hline Atribut Yang Diuji & $\begin{array}{c}\text { Nilai Uji } \\
\text { Validitas }\end{array}$ & Keterangan \\
\hline Harga & 0,459 & Valid \\
Rasa & 0,462 & Valid \\
Varianrasa & 0,318 & Valid \\
Ukuran & 0,541 & Valid \\
Tekstur & 0,672 & Valid \\
Kemasan produk & 0,520 & Valid \\
Kemudahan & 0,364 & Valid \\
memperoleh & Nilai & \\
\hline Reliabilitas & 0,752 & \\
Cronbach’ Alpha &
\end{tabular}

Hasil dari uji reliabilitas didapat dari perhitungan menggunakan program SPSS, dan pengujian reliabilitas menggunakan uji statistik Cronbach Alpha, dikatakan reliabel dengan standar dapat diterima jika memberikan nilai Cronbach Alpha $>0,70$ (Sugiyono 2012).

Pada Tabel 1 dapat diketahui bahwa semua variabel dikatakan valid karena nilai corrected item dari total correlation sudah di atas 0,20 dan hasil uji reliabilitas dari 7 atribut menunjukkan bahwa nilai Cronbach's Alpha tingkat kepentingan di CV Mayang Sari di Kota Bandar Lampung sebesar $(0,752)$ yang berarti semua pertanyaan yang diajukan di dalam kuesioner dinyatakan reliable karena nilainya > 0,70 .

Hasil uji validitas dan reliabilitas pada tingkat kepercayaan bolen pisang CV Mayang Sari Kota Bandar Lampung, dikatakan valid karena nilai corrected item dari total correlation bernilai di atas 0,20. Apabila nilai korelasi butir corrected item dari butir total correlation sudah di atas 0,20 maka butir-butir tersebut dikatakan valid dan hasil uji reliabilitas sebesar $(0,819)$ yang berarti semua pertanyaan yang diajukan di dalam kuesioner juga dinyatakan reliable karena nilainya $>0,70$ disajikan pada Tabel 2.

Untuk mengetahui sikap konsumen terhadap bolen pisang digunakan metode Multiatribut Fishbein. Model ini secara singkat menyatakan bahwa sikap seorang konsumen terhadap suatu objek akan ditentukan oleh sikapnya terhadap berbagai atribut yang dimiliki oleh objek tersebut. Model multiatribut Fishbein menurut Setiadi (2003), diformulasikan dalam rumus :

$$
\mathrm{Ao}=\sum_{1=1}^{\mathrm{N}} 1 \text { bi. ei }
$$

Keterangan :

Ao $=$ Skor sikap terhadap produk

bi $=$ Kekuatan kepercayaan bahwa merk

„,X"memiliki atribut $\mathrm{i}$

ei $=$ Evaluasi mengenai atribut ke-i

$\mathrm{n}=$ Jumlah atribut

$\mathrm{i}=$ Atribut ke-I $(1,2,3, \ldots, \mathrm{n})$

Ao (attitude toward the object) diukur dengan menggunakan model Multiatribut Fishbein melalui penilaian atribut yang ada pada bolen pisang CV Mayang Sari. Sikap konsumen terhadap atribut dinilai berdasarkan tingkat kepentingan (ei) dan tingkat kepercayaan (bi). Tingkat kepentingan (ei) untuk mengukur evaluasi konsumen terhadap atribut - atribut dari bolen pisang CV Mayang Sari secara umum tanpa adanya pengikatan dengan merek tertentu. Tingkat kepercayaan (bi) untuk mengukur atribut yang ada pada bolen pisang CV Mayang Sari.

Customer satisfaction Index (CSI) dan Importance and Performance Analysis (IPA) digunakan untuk mengetahui tingkat kepuasan konsumen. CSI digunakan untuk mengetahui berapa persen tingkat kepuasan konsumen terhadap suatu produk atau jasa. Terdapat empat tahapan dalam menilai keputusan melalui CSI. Pertama adalah Weighted Factor (WF), Ke dua Weighted Score (WS), ke tiga Weighted Total (WT), dan keempat Satisfaction Indeks. Tingkat kepuasan konsumen secara keseluruhan dapat dilihat dari kriteria tingkat kepuasan yang berdasarkan panduan survei kepuasan pelanggan yaitu sangat tidak puas kepuasan pelanggan yaitu sangat tidak puas $(0,00-0,20)$, tidak puas $(0,21-0,40)$, cukup puas $(0,41$ $0,60)$, puas $(0,61-0,80)$, dan sangat puas $(0,81-1,00)$ (Supranto 2006).

Tabel 2. Hasil uji validitas dan reliabilitas atribut tingkat kepercayaan bolen pisang $\mathrm{CV}$ Mayang Sari

\begin{tabular}{lcc}
\hline \multicolumn{1}{c}{ Atribut Yang Diuji } & $\begin{array}{c}\text { Nilai Uji } \\
\text { Validitas }\end{array}$ & Keterangan \\
\hline Harga & 0,508 & Valid \\
Rasa & 0,505 & Valid \\
Varianrasa & 0,660 & Valid \\
Ukuran & 0,558 & Valid \\
Tekstur & 0,591 & Valid \\
Kemasan produk & 0,639 & Valid \\
Kemudahan memperoleh & 0,471 & Valid \\
\hline Reliabilitas & Nilai & \\
Cronbach' Alpha & 0,819 & \\
\hline
\end{tabular}


Importance and Performance Analysis (IPA) digunakan untuk menggambarkan kinerja yang dipersepsikan oleh konsumen dalam bentuk Diagram kartesius yang digunakan dalam menentukan kuadran yang terdapat pada analisis IPA. Kuadran pada IPA yaitu kuadran I (prioritas utama), kuadran II (pertahankan prestasi), kuadran III (prioritas rendah) dan kuadran IV (kinerja berlebih).

\section{HASIL DAN PEMBAHASAN}

\section{Karakteristik Konsumen}

Karakteristik konsumen berdasarkan jenis kelamin menunjukkan bahwa konsumen yang berjenis kelamin laki-laki sebanyak 24 orang dan perempuan sebanyak 16 orang, yang didominasi oleh konsumen yang berusia 24-30 tahun yaitu (44\%). Hal ini menunjukkan bahwa sebagian besar pengunjung CV Mayang Sari tergolong kelompok usia produktif dan sebagian besar masih kuliah atau baru bekerja. Menurut Mantra (2004), kelompok usia produktif ialah kelompok penduduk yang memiliki usia kisaran 15-64 tahun.

Konsumen yang membeli dan atau mengonsumsi bolen pisang di CV Mayang Sari sebagian besar berpendidikan terakhir SMA yaitu sebanyak 23 orang dengan pendapatan sebesar Rp1.500.000,00 - Rp2.500.000,00. Tingkat pendidikan dapat mempengaruhi konsumen dalam melakukan pembelian makanan, karena konsumen yang memiliki pendidikan yang lebih tinggi akan akan mengonsumsi makanan yang lebih baik dan aman bagi tubuhnya. Pekerjaan konsumen bolen pisang di CV Mayang Sari sebagian besar adalah karyawan swasta (33\%). Hal ini dikarenakan lokasi CV Mayang Sari yang berada di dekat beberapa kantor sehingga pengunjungnya didominasi oleh karyawan swasta.

\section{Sikap Konsumen}

Berdasarkan hasil perhitungan Multiatribut Fishbein diperoleh nilai kepentingan produk bahwa atribut rasa bolen pisang CV Mayang Sari merupakan atribut yang mendapatkan nilai tertinggi oleh konsumen dalam membeli dan atau mengkonsumsi bolen pisang CV Mayang Sari di Kota Bandar Lampung dibandingkan dengan atribut lainnya dengan nilai sebesar 4,63.
Tabel 3. Skor evaluasi kepentingan (ei) terhadap bolen pisang CV Mayang Sari

\begin{tabular}{lcccccc}
\hline \multirow{2}{*}{ Atribut } & \multicolumn{9}{c}{ Tingkat Kepentingan (ei) } & Rata-rata \\
\cline { 2 - 6 } & 1 & 2 & 3 & 4 & 5 & $(\mathrm{ei})$ \\
\hline Harga & 0 & 0 & 2 & 13 & 25 & 4,58 \\
Rasa & 0 & 0 & 3 & 9 & 28 & 4,63 \\
Varian rasa & 0 & 1 & 9 & 11 & 19 & 4,20 \\
Ukuran & 0 & 1 & 7 & 10 & 22 & 4,33 \\
$\begin{array}{l}\text { Tekstur } \\
\text { Kemasan }\end{array}$ & 0 & 0 & 7 & 11 & 22 & 4,38 \\
produk & 1 & 0 & 5 & 11 & 23 & 4,38 \\
$\begin{array}{l}\text { Kemudahan } \\
\text { memperoleh }\end{array}$ & 0 & 0 & 5 & 11 & 24 & 4,48 \\
\hline
\end{tabular}

Hal ini sejalan dengan penelitian Marbun dkk. (2015) dan Kuswara (2013) yang mendapatkan bahwa skor atribut rasa memperoleh skor tertinggi pada pancake durian dan lapis bogor. Atribut bolen pisang lainnya yang dianggap penting oleh konsumen adalah atribut harga dengan skor evaluasi (ei) sebesar 4,58. Konsumen akan membeli bolen pisang dengan harga yang murah dan terjangkau. Menurut Kartajaya (2002) indikator harga dapat dinyatakan dalam penilaian konsumen terhadap besarnya pengorbanan finansial yang diberikan dalam kaitannya dengan spesifikasi yang berupa kualitas produk.

Setelah mengetahui skor kepentingan yang ada pada atribut bolen pisang CV Mayang Sari di Kota Bandar Lampung selanjutnya mengetahui penilaian kepercayaan responden (bi). Penilaian kepercayaan responden ini terdiri dari masingmasing atribut yang diteliti yaitu harga, rasa, varian rasa ukuran, tekstur, kemasan produk, dan kemudahan memperoleh. Hasil penelitian skor tingkat kepercayaan (bi) terhadap bolen pisang CV Mayang Sari di Kota Bandar Lampung dapat dilihat pada Tabel 4.

Tabel 4. Skor tingkat kepercayaan (bi) terhadap bolen pisang CV Mayang Sari

\begin{tabular}{|c|c|c|c|c|c|c|}
\hline \multirow[t]{2}{*}{ Atribut } & \multicolumn{5}{|c|}{$\begin{array}{c}\text { Tingkat Kepercayaan } \\
\text { (bi) }\end{array}$} & \multirow{2}{*}{$\begin{array}{l}\text { Rata-rata } \\
\text { (bi) }\end{array}$} \\
\hline & 1 & 2 & 3 & 4 & 5 & \\
\hline Harga & 0 & 0 & 2 & 13 & 25 & 4,58 \\
\hline Rasa & 0 & 0 & 5 & 13 & 22 & 4,43 \\
\hline Varian rasa & 0 & 0 & 7 & 14 & 19 & 4,30 \\
\hline Ukuran & 0 & 0 & 8 & 19 & 13 & 4,13 \\
\hline Tekstur & 0 & 1 & 5 & 20 & 14 & 4,18 \\
\hline $\begin{array}{l}\text { Kemasan } \\
\text { Produk }\end{array}$ & 0 & 1 & 8 & 19 & 12 & 4,05 \\
\hline $\begin{array}{l}\text { Kemudahan } \\
\text { memperoleh }\end{array}$ & 0 & 2 & 5 & 12 & 21 & 4,30 \\
\hline
\end{tabular}


Data pada Tabel 4 dapat dilihat bahwa tingkat kepercayaan (bi) tertinggi pada atribut harga sebesar 4,58 yang artinya atribut harga dinilai murah oleh konsumen karena sesuai dengan harapan konsumen terhadap bolen pisang CV Mayang Sari tersebut. Atribut kemasan produk memperoleh nilai kepercayaan (bi) terendah dengan skor kepercayaan sebesar 4,05 yang artinya atribut kemasan produk tesebut cukup menarik. Hal ini berbeda dengan penelitian Epriani dkk. (2017) yang menyatakan bahwa atribut rasa merupakan skor sikap tertinggi bila dibandingkan dengan atribut lainnya karena atribut rasa dianggap mempengaruhi konsumen ketika ingin melakukan pembelian terhadap kopi bubuk di Bandar Lampung.

atribut-atribut bolen pisang CV. Mayang Sari diukur dengan menggunakan model multiatribut Fishbein dimana konsumen memberikan penilaian terhadap tingkat kepentingan dan tingkat kepercayaan sehingga dapat diketahui sikap konsumen terhadap bolen pisang CV Mayang sari.

Hasil perhitungan model sikap dengan menggunakan rumus multiatribut Fishbein, diperoleh skor sikap terhadap bolen pisang. Berdasarkan Tabel 5 terlihat bahwa hasil perkalian komponen tingkat kepentingan atribut (ei) dan tingkat kepercayaan atribut (bi) diperoleh skor sikap konsumen (Ao) yang didapatkan adalah 132,52. Nilai ini digunakan untuk mengetahui penilaian sikap konsumen terhadap bolen pisang dengan menentukan rating scale terlebih dahulu. Perhitungan skor ideal (kriterium) merupakan skor yang digunakan untuk menghitung skor rating scale dan jumlah seluruh jawaban yang didapatkan dari skor jawaban tiap pertanyaan dikalikan dengan jumlah responden.

Tabel 5. Skor multi atribut sikap (Ao) terhadap atribut bolen pisang CV Mayang Sari

\begin{tabular}{|c|c|c|c|}
\hline Atribut & $\begin{array}{c}\text { Skor } \\
\text { Tingkat } \\
\text { Kepentingan } \\
\text { (ei) }\end{array}$ & $\begin{array}{c}\text { Skor } \\
\text { Tingkat } \\
\text { Kepercayaan } \\
\text { (bi) }\end{array}$ & $\begin{array}{l}\text { Skor } \\
\text { Sikap }\end{array}$ \\
\hline Harga & 4,58 & 4,58 & 20,93 \\
\hline Rasa & 4,63 & 4,43 & 20,47 \\
\hline Varian rasa & 4,20 & 4,30 & 18,06 \\
\hline Ukuran & 4,33 & 4,13 & 17,84 \\
\hline Tekstur & 4,38 & 4,18 & 18,27 \\
\hline $\begin{array}{l}\text { Kemasan } \\
\text { produk }\end{array}$ & 4,38 & 4,05 & 17,72 \\
\hline $\begin{array}{l}\text { Kemudahan } \\
\text { memperoleh }\end{array}$ & 4,48 & 4,30 & 19,24 \\
\hline $\mathrm{Ao}=\sum$ ei.bi & & & 132,52 \\
\hline
\end{tabular}

Tabel 6. Hasil rating scale dari jumlah skor ideal (kriterium)

\begin{tabular}{lrc}
\hline Skor kriterium & \multicolumn{1}{c}{ Hasil } & Skala \\
\hline $5 \times 40=200$ & $161-200$ & Sangat Baik \\
$4 \times 40=160$ & $121-160$ & Baik \\
$3 \times 40=120$ & $81-120$ & Cukup Baik \\
$2 \times 40=80$ & $41-80$ & Kurang Baik \\
$1 \times 40=40$ & $0-40$ & Sangat Kurang \\
& & Baik \\
\hline
\end{tabular}

Hasil perhitungan skor kriterium menggunakan rating scale berdasarkan Sugiyono (2012) dapat dilihat pada Tabel 6. Berdasarkan kategori sikap konsumen tersebut, dapat diketahui bahwa sikap konsumen terhadap bolen pisang yang memiliki nilai 132,52 berada pada interval 121-160, yang berarti berada dalam kategori baik. Hal ini sejalan dengan penelitian Frisdinawati dan Priyono (2012) yang mendapatkan bahwa nilai sikap total konsumen terhadap paket donat Surya Bakery di Kota Bengkulu berada pada kategori baik. Atribut harga memperoleh skor (Ao) tertinggi sebesar 20,93 sedangkan atribut yang memperoleh skor (Ao) terendah adalah atribut kemasan produk dengan skor sebesar 17,72. Penelitian ini sejalan dengan penelitian Andela dkk. (2019) menyatakan bahwa atribut rasa merupakan atribut yang dianggap sangat penting oleh konsumen pie pisang.

\section{Pola Pembelian}

1) Jumlah bolen pisang yang dibeli

Jumlah pembelian adalah banyaknya bolen pisang yang dibeli oleh responden dalam jangka waktu enam bulan terakhir. Jumlah pembelian bolen pisang yang dilakukan oleh responden dalam penelitian ini cukup beragam. Jumlah pembelian bolen pisang berkaitan dengan jumlah anggota keluarga konsumen. Jumlah pembelian bolen pisang terbesar oleh konsumen dalam satu bulan terakhir adalah sebanyak 4 kotak bolen pisang dengan jumlah responden sebesar 2 orang (5\%), dan yang paling terkecil 2 kotak bolen pisang yaitu 21 orang $(52,50 \%)$. Dalam satu kotak bolen pisang berisi 10 buah dengan harga jual $\mathrm{Rp}$ 30.000/kotak. Rata-rata perbulan dalam satu kali pembelian responden membeli 2 kotak bolen pisang . 
2) Frekuensi pembelian bolen pisang

Frekuensi pembelian adalah besaran yang mengukur jumlah repetisi pembelian dari setiap pembelian bolen pisang yang dinyatakan dalam satuan berapa kali per bulan. Frekuensi pembelian responden terhadap bolen pisang berkaitan dengan kepentingan responden dalam mengkonsumsi bolen pisang. Responden dalam penelitian ini menyatakan bahwa dalam satu bulan melakukan pembelian bolen pisang sebanyak dua kali per bulan. Sebagian besar konsumen melakukan pembelian bolen pisang sebanyak satu kali perbulan yaitu sebanyak 36 responden (90\%) dan empat responden (10\%) melakukan pembelian dua kali perbulan.

3) Jenis bolen pisang yang dibeli

Terdapat beberapa jenis bolen pisang pada CV Mayang Sari Kota Bandar Lampung yaiut coklat, keju, dan tape. Jenis bolen pisang yang paling diminati atau terbanyak dibeli ialah coklat dengan jumlah 22 responden (55\%) dan yang paling rendah jenis bolen pisang tape dengan jumlah 11 responden $(27,50 \%)$.

\section{Kepuasan Konsumen}

Metode CSI merupakan metode pengukuran kepuasan konsumen yang sering dipakai untuk melihat atau mengukur kepuasan konsumen. Metode ini mengukur kepuasan konsumen secara keseluruhan (Index satisfaction) dari tingkat kepentingan (importance) dan tingkat kinerja (performance) (Supranto 2006). Berdasarkan pada Tabel 9, nilai Weighted Score Total bolen pisang sebesar 4,19. Untuk menghasilkan nilai indeks angka yang tinggi, CV. Mayang Sari harus memperhatikan tingkat kepentingan dan kinerja seluruh atribut produknya bagi konsumen

Nilai CSI pada produk bolen pisang yaitu sebesar 83,82 persen atau sebesar 0,83 yang berarti konsumen sangat puas, sesuai dengan pembagian kriteria menurut Irawan (2002) bahwa jika nilai CSI berada pada rentang 0,81-1,00 artinya sangat puas. Pengukuran terhadap kepuasan konsumen diperlukan untuk mengetahui bagaimana tanggapan konsumen setelah mengonsumsi suatu produk sehingga dapat menentukan sasaran di masa mendatang
Tabel 9. Perhitungan menggunakan metode Customer Satisfaction Index (CSI) bolen pisang CV Mayang Sari

\begin{tabular}{|c|c|c|c|c|}
\hline Atribut & $\begin{array}{c}\text { Atribut } \\
\text { Tingkat } \\
\text { Kepentingan } \\
\text { (RSP) }\end{array}$ & $\begin{array}{l}\text { Weighting } \\
\text { Factors } \\
\text { (WF) }\end{array}$ & $\begin{array}{l}\text { Tingkat } \\
\text { Kinerja } \\
\text { (RSK) }\end{array}$ & $\begin{array}{c}\text { Veighted } \\
\text { Score } \\
\text { (WS) }\end{array}$ \\
\hline Harga & 4,25 & 0,15 & 4,25 & 0,64 \\
\hline Rasa & 4,18 & 0,15 & 4,15 & 0,62 \\
\hline Varian rasa & 4,00 & 0,14 & 4,48 & 0,63 \\
\hline Ukuran & 3,98 & 0,14 & 3,95 & 0,56 \\
\hline Tekstur & 4,00 & 0,14 & 4,23 & 0,60 \\
\hline $\begin{array}{l}\text { Kemasan } \\
\text { produk }\end{array}$ & 3,90 & 0,14 & 4,60 & 0,63 \\
\hline $\begin{array}{l}\text { Kemudahan } \\
\text { memperoleh }\end{array}$ & 3,83 & 0,14 & 3,78 & 0,51 \\
\hline Total & 28,13 & 1 & 29,44 & \\
\hline $\begin{array}{l}\text { Weighted } \\
\text { Total (WT) }\end{array}$ & & & & 4,19 \\
\hline $\begin{array}{l}\text { Customer } \\
\text { Satisfaction } \\
\text { Index }\end{array}$ & \multicolumn{2}{|c|}{$(\mathrm{CSI})=(4,19: 5) \times 100 \%$} & & $83,82 \%$ \\
\hline
\end{tabular}

Penelitian ini sejalan dengan penelitian yang dilakukan Kurniati dkk. (2016) dan Pradita dkk (2013) bahwa diperoleh nilai CSI produk Kue Baytat Bengkulu sebesar 0,80 yang artinya konsumen berada pada kriteria puas. Walaupun demikian, tingkat kepuasan konsumen perlu terus ditingkatkan lagi hingga mendekati (100\%) agar semua atribut memberikan nilai kepuasan tertinggi bagi konsumen.

\section{Importance Performance Analysis}

CSI bolen pisang CV Mayang Sari masih berada di bawah 100 persen. Hal tersebut menunjukkan bahwa bolen pisang CV Mayang Sari masih perlu usaha untuk meningkatkan kepuasan konsumen. Kinerja yang perlu ditingkatkan dalam atribut bolen pisang dapat dianalisis dengan menggunakan metode IPA, menggunakan Diagram Kartesius. Kombinasi antara sumbu kepentingan (importance) dan sumbu kinerja (performance) akan menghasilkan posisi dari masing-masing atribut.

Berdasarkan Gambar 1 atribut-atribut tersebut tersebar ke dalam Diagram Kartesius IPA. Atribut yang berada pada kuadran I (prioritas utama) adalah atribut rasa, kuadran II (pertahankan prestasi) terdapat atribut harga, kuadran III (prioritas rendah) terdapat atribut ukuran dan atribut kemudahan memperoleh, dan pada kuadran IV (berlebihan) terdapat atribut tekstur, varian rasa, dan atribut kemasan produk. 


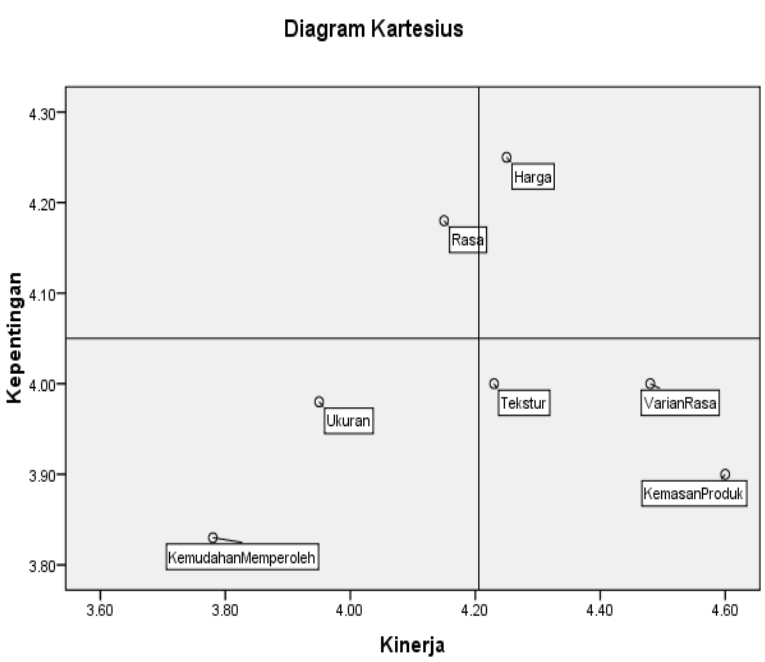

Gambar 1. Diagram Kartesius Importance Performance Analysis

Hasil analisis Gambar 1 dapat dijelaskan sebagai berikut:

1) Kuadran I (Prioritas utama)

Atribut yang terdapat pada kuadran I adalah atribut rasa. Nilai kepentingan dari atribut rasa bolen pisang adalah sebesar 4,18 yang artinya sangat penting bagi konsumen dan nilai kinerjanya 4,15 yang artinya konsumen merasa belum puas dengan atribut ini, dikarenakan atribut ini masuk kedalam kuadran I yang artinya atribut rasa dianggap sangat penting namun kinerjanya masih rendah atau belum maksimal seperti apa yang diharapkan oleh konsumen. Oleh karena itu, perusahaan perlu memperbaiki atau memaksimalkan rasa bolen pisang untuk meningkatkan kepuasan konsumen.

2) Kuadran II (Pertahankan prestasi)

Atribut yang berada pada kuadran II adalah atribut harga, bahwa atribut tersebut dianggap penting dan memenuhi keinginan konsumen sehingga harus dipertahankan. Upaya yang dilakukan oleh CV Mayang Sari untuk tetap dapat mempertahankan atribut harga yaitu dengan mempertahankan harga yang telah ditetapkan, dikarenakan harga bolen pisang tersebut dianggap sudah dapat memenuhi keinginan konsumen karena harga yang diberikan pihak CV Mayang Sari relatif sama dengan agroindustri lainnya bahkan lebih murah dari agroindustri yang lain. Atribut ini perlu dipertahankan agar konsumen tetap merasa puas dalam melakukan pembelian.
Hal ini sejalan dengan penelitian Syarifatunisa (2011) yang menyatakan bahwa atribut harga yang terjangkau dianggap penting oleh konsumen Toko Roti Unyil Venus Bogor.

3) Kuadran III (Prioritas rendah)

Terdapat atribut ukuran dan kemudahan memperoleh produk pada kuadran III, dimana atribut-atribut tersebut kepentingannya dianggap rendah serta pada kenyataan kinerja yang diberikan masih rendah. Atribut kemudahan dalam memperoleh dianggap tidak terlalu penting oleh konsumen karena lokasi CV Mayang Sari sudah cukup strategis yaitu berada dipinggir jalan raya. Nilai kepentingan atribut ini sebesar 3,83 dan nilai kinerjanya sebesar 3,78. Kemudahan akses ke lokasi pada penelitian ini adalah mudah atau tidaknya lokasi CV Mayang Sari untuk dikunjungi atau dijangkau oleh banyak kendaraan. Mudahnya akses bagi kendaraan untuk menuju CV Mayang Sari tersebut, sehingga membuat atribut kemudahan dalam memperoleh produk dianggap tidak terlalu penting.

4) Kuadran IV (Berlebihan)

Atribut yang berada pada kuadran ini adalah atribut varian rasa, tekstur, dan kemasan produk, yang merupakan atribut-atribut yang dinilai kurang penting tetapi dalam pelaksanaannya dilaksanakan sangat baik dan terkesan berlebihan. Konsumen merasa puas dengan pelaksanaan atribut pada kuadran IV namun, pelaksanaan yang berlebihan sehingga pihak perusahaan dapat mengurangi dalam pelaksanaannya

\section{KESIMPULAN}

Sikap konsumen untuk membeli bolen pisang CV Mayang Sari berada dalam kategori baik yang memiliki nilai 132,52. Rata-rata jumlah pembelian bolen pisang CV Mayang Sari oleh konsumen adalah dua kotak bolen pisang dalam satu kali transaksi dengan varian rasa yang paling diminati konsumen adalah coklat (55\%). Frekuensi pembelian konsumen (90\%) dilakukan sebanyak dua kali dalam satu bulan. Tingkat kepuasan konsumen dengan menggunakan analisis dalam mengkonsumsi bolen pisang CV Mayang Sari berada pada kriteria sangat puas yaitu sebesar (83,82\%). Berdasarkan Diagram Kartesius terdapat satu atribut yang masuk ke dalam kuadran I (Prioritas Utama) yaitu atribut rasa. Pada kuadran II (Pertahankan Prestasi) terdapat 
satu atribut yaitu atribut harga, sedangkan pada kuadran III (Prioritas Rendah) terdapat atribut ukuran dan kemudahan memperoleh produk, dan pada kuadran IV (Berlebihan) terdapat beberapa atribut yaitu tekstur, varian rasa, dan kemasan produk.

\section{DAFTAR PUSTAKA}

Andela WE, Endaryanto T, dan Adawiyah R. 2019. Sikap, pengambilan keputusan, dan kepuasan konsumen terhadap agroindustri pie pisang di Kota Bandar Lampung. Jurnal Ilmu Ilmu Agribisnis, 8 (2) : 310317.http://jurnal.fp.unila.ac.id/index.php/JIA /article/view/4070/2965.[11 November 2020].

Direktorat Jendral Hortikultura. 2015. Statistik Produksi Hortikultura Tahun 2014. Jakarta.

Epriani $\mathrm{M}$, Indriani $\mathrm{Y}$, dan Endaryanto $\mathrm{T}$. 2017. Sikap konsumen dan strategi pemasaran dua merek kopi bubuk di Kota Bandar Lampung. Jurnal Ilmu Ilmu Agribisnis, $\quad 5 \quad$ (4) : $414 \quad-$ 421.http://jurnal.fp.unila.ac.id/index.php/J IA/article/view/1751/1554. [4 Juli 2020].

Frisdinawati D dan Priyono BS. 2012. Analisis sikap dan perilaku konsumen terhadap produk donat paket Surya Bakery di Kota Bengkulu. Jurnal Agrisep, Vol. 11 No. 2. https://media.neliticom/media/publications/ 37309-ID-analisis-sikap-dan-perilakukonsumen-terhadap-produk-donat-paketsurya-bakery-di.pdf. [20 Januari 2020].

Ghozali I. 2009. Aplikasi Analisis Multivariate dengan Program SPSS. Edisi ke-4. Universitas Diponegoro. Semarang.

Irawan H. 2002. 10 Prinsip Kepuasan Pelanggan. PT. ElexMedia Komputindo. Jakarta.

Kartajaya H. 2002. Hermawan Kartajaya On Marketing. PT. Gramedia Pustaka Utama. Jakarta
Kurniati E, Silvia E, dan Efendi Z. 2016. Analisis Kepuasan konsumen terhadap kue baytat bengkulu. Jurnal Teknologi dan Pertanian $\begin{array}{lllll}\text { Indonesia } & (J T I P) . & 8 & (2): & 67-75 .\end{array}$ http://jurnal.unsyiah.ac.id/TIPI/article/view/6784. [11 Agustus 2020]

Kuswara. 2013. Analisis Perilaku dan Kepuasan dalam Proses Keputusan Pembelian Lapis Bogor Sangkuriang. Skripsi. Institut Pertanian Bogor. Bogor. http://repository.ipb.ac.id/jspui/bitstream/12 3456789/67664/1/H13eku.pdf. September 2019].

Malhotra N. 2006. Marketing Reseach: An Applied Oriented. 5th Edition. Prentice Hall. Upper Saddle River. New Jersey

Mantra IB. 2004. Demografi Umum. Pustaka Pelajar. Yogyakarta.

Marbun D, Priyono BS, dan Suryanti M. 2015. Analisis persepsi, sikap dan perilaku konsumen terhadap pancake durian (Studi kasus : Pancake durian produksi Celebrity Pancake). AGRISEP, (15) 2: 215-226. https://ejournal.unib.ac.id/index.php/agrisep/ article/view/839/734 [23 Februari 2021].

Pradita R, Indriani Y, dan Soelaiman A. 2016. Tingkat kepuasan dan loyalitas konsumen tauco di Kota Prabumulih. Jurnal Ilmu Ilmu Agribisnis, 4(1) : 86-93. http://jurnal. fp. unila.ac.id/index.php/JIA/article/view/1218/1 115. [24 Desember 2020].

Setiadi J. 2003. Perilaku Konsumen (Konsep Implikasi Untuk Strategi dan Penelitian Pemasaran). Prenada Media. Jakarta

Supranto J. 2006. Pengukuran Tingkat Kepuasan Pelanggan untuk Menaikan Pangsa Pasar. Rineka Cipta, Jakarta.

Sugiyono. 2012. Metode Penelitian Kunatitatif Kualitatif dan $R \& D$. Alfabeta.Bandung.

Syarifatunisa. 2011 Analisis Strategi Peningkatan Kepuasan Pelanggan Toko Roti Unyil Venus Bogor . Skripsi. Institut Pertanian Bogor. Bogor. 